\title{
Alignment of Global Marketing Strategies Through Self-concept in Consumer Behavior
}

\author{
Sabah J. Alwan \\ The College of Saint Scholastica, Minnesota, USA
}

\begin{abstract}
Integration of global marketing in continuous, emerging, market segments coupled with product mobility through multi-distribution global channels have become profitable but, also challenging, to global marketers. The study researched the relationship between consumer behavior and self-concept in adopting a product in mature (United States) and fragmented (Arabian Peninsula/North Africa) markets. The global marketer should develop a global strategic alignment plan that understands the effectiveness of complex distribution channels and how global consumers think and behave in terms of his/her self-concept in purchasing the product. Organizations in the United States are battling the toughest, domestic, competitions from global organizations that are strategically aligned and have executed their global marketing strategies in the most competitive and mature markets in the world. This marketing phenomenon to the American market and its' consumers, who score very high on patriotic affiliation and American products global market share and how global consumers behave towards it, in relation to other competing, global products are challenging. In reality, there are two factors which drive the majority of products in the global market: The first factor is the product's country of origin's political orientation within the world stage; and the second factor is the customer-centered measures strategy. Research data which were analyzed through empirical and percentage scale of $8.6 \%$ were factored in every 12 years starting from 1982 to 1970 for the American automobile global share. Japanese automobile market share percentage rate of change was used to subtract every 12 years starting from 1982 to 1970 . The result of study showed that the first factor has a high effect on consumer behavior in the fragmented market and a lower effect on consumer behavior in the mature market. As for the second factor, the result of the study showed that there are the same level of effects in both mature and fragmented markets.
\end{abstract}

Keywords: self-concept, mature market, fragmented market, spherical market, clustering market, behavioral alignment, product's country of origin, customer-centered measures strategy

\section{Introduction}

Worth noting is that the United States global market share ranked $40.3 \%$ in the 1963, then dropped to $27 \%$ in 2000 and to a low of $11 \%$ in 2001 (Hill, 2004, p. 21). In 2011, the American merchandise exports ratio within the world output was $13 \%$, and it was $\$ 2.28$ trillion (WTO, 2011). Furthermore, the forecast of the American Gross Domestic Products (GDP) world output is not a promising, supportive outlook to the

Sabah J. Alwan, Professor of Leadership \& Organizational Behavior, School of Business and Technology, The College of St. Scholastica.

Correspondence concerning this article should be addressed to Sabah J. Alwan, The College of St. Scholastica, 1200 Kenwood Ave, Duluth, Minnesota, 55811, USA. E-mail: salwan@css.edu. 
American global organizations. This reinforces the idea of global marketing to be re-strategized in tactical and strategic methods. This new strategic vision alignment is seeking to look inward towards understanding the self-concept of the global consumers' behavior. The other part of the strategic method is how the global organization can affect the modification of their government's political standing within the world stage. In 2015, the United States share of world total GDP is forecasted to be $18.28 \%$. This trend affects the American automotive market share, due to the fact that automotive production represents a considerable percentage of the GDP of the United States as one of the main exports that have some effects on the United States balance of trade. Also, the ramifications of the automotive industry have many positive or negative effects on the American economy. Historically, from 1947 until 2013, the United States GDP growth rate averaged 3.23\%, reaching an all-time high of $17.20 \%$ in March of 1950 and a record low of 10.40\% in March of 1958 (Trading Economics, 2013). The American world output started to wind down sharply in the early 1990s and continued on a downward trend until 2002, to hold at a fluctuating percentage at approximately $12 \%$ to $15 \%$. The decline of the global market share of American products in general, can represent a new phenomenon in the global marketing strategy that many global organizations are utilizing and venturing within the global market. Also, the decline in the number of American multinational companies from 48\% in 1973 to $26 \%$ in 2000 is another indicator of a strong global rivalry and competitive global products (Hill, 2004, p. 24). This phenomenon has its roots in two factors: First, product's country of origin's political orientation within the world stage which is centralized around the relationship of the country's product and foreign policy toward world affairs. This relation often affects the consumer's behavior either in a negative or positive form. The foreign policy of the product's country has a substantial direct effect on the consumer's acceptance of the product. This direct affect has degrees of negative outcomes on consumer adoption to that product. "International firms are affected by the local political events in every country where they operate. Furthermore, both domestic and international firms can be influenced by the actions of international governmental and nongovernmental organizations" (Jackson \& Schuler, 2003, p. 47). Consumers in a country that suffers minor negative effects by the products' country of origin's foreign policy which has a lesser negative effect on consumers' behavior in accepting the product. An applicable example of this is Venezuelan's consumers purchasing less American products; where American foreign policy or political ideology does not directly influence Venezuelans' consumer behavior since the socialist revolution by Hugo Chavez. A direct affect of the first factor is a stronger, negative outcome on consumers who have been directly affected by the products' country of origin's foreign policy. This takes place in a country in which the consumer has a strong, self-concept, political, and ethical beliefs in issues that have been harmed by the products' country's foreign policy actions. A good example is American products in the Arab World. This translates to a considerable reduction of adoption of the product by the consumer. This consumer behavior can be seen even if the American products are compatible in quality to competitors' products. This can be observed and successfully contended, even in the countries of the strongest political and economic American allies, such as Saudi Arabia. The second factor is the customer-centered measures strategy, which encompasses four key drivers (customer acquisition, customer retention, customer lifetime value, and customer equity). The customer-centered measures strategy is a byproduct of the first factor. In order for any global marketing strategy to take establishment in any market, the global organization should recognize the relationship between the consumer behavior and product's country of origin's political orientation within the world stage. If the relationship is positive, then the global organization should start strategizing around the second factor (customer-centered measures). It is very intriguing to exemplify how global organizations such as 
British Petroleum (BP) as one of the strongest Western European allies to the United States, are practicing reduction of the source effect theory on the American consumers by hiding their original names through their logo brands of BP. Therefore, one should not be surprised to see the effect of the first factor of the product's country of origin's political orientation on consumer behavior within the global market. This research will use the automobile as a consumer's behavior decision indicator. The fact that vehicles are one of the products which often reflect consumers' personalities, self-concepts, and their stances on world issues, the first factor greatly impacts the consumers' behavior decisions, therefore, it is a widely applicable example to apply within many different markets of the world.

\section{Global Organization Strategy in the Mature Market}

The strategic global vision of some international organizations in a mature market such as, the United States, has established marketing plans that have matured through decades of social and market alignments according to the consumer's self-concept and behavior segments. These global organizations' market alignment strategy often starts with the applications of the first factor "product's country of origin's political orientation" by reducing the source effect theory drivers on the American consumers, especially by Asian organizations. Some of the American consumers' infamous, negative drivers of the 1950s and 1960s are that the Asian automobile had less quality and it was more expensive. Both drivers can hold some truth within the conviction of the American consumers. Both of the negative drivers are the result of lack of the economy of scale and maturity of the operational plan on the part of the Japanese auto manufacturing in the 1950s and 1960s. The cause of this can be argued successful due to the effect of World War II on Japan's infrastructure. "Japanese manufacturing seen as sub-par and in the 1950s, American car companies have huge economies of scale" (Halberstam, 1986, p. 28). To align the strategy of the first factor, the global organization had executed their marketing plan by targeting diverse, multipliable segments of the American consumer. This strategy is implemented by appealing to the (self-concept) political, social, and ethical needs of the American consumer. Continuous political support of Asian companies' governments to the American political stand on the world stage facilitates the positive attitude modifications of the American consumer. Also, the domestic support of Asian global organizations to the American economy is an accelerator into a positive conversion of attitudes toward such organizations. All this is executed through the establishment of many manufacturing plants in many American states. This has a continuous, positive effect on the American consumer in aligning consumers' beliefs through the first factor (product's country of origin's political orientation). The achievement of a consumers' positive view to the global product through the first factor is a limitless accomplishment by the global organization. At this stage, the global organization has achieved success in modifying the America consumers' behaviors toward accepting and adopting the products. The next step is move to the second factor: customer-centered measures strategy. This is often executed through convincing the American consumer that international products, especially Asian products, are worthy of true quality and added value to the consumers' long-life needs. Hyundai Motor was the first Asian global organization that offered a 10-year warranty on its products. This was a very bold move by Hyundai Motor in a mature market that is highly competitive and a market sanctuary to a prevalently global American automotive brand. This tactical marketing move is to increase customers' positive perception and then product acquisition. Hyundai Motor quickly provided technical, expert support to back up the 10-year warranty and go beyond the warranty, delighting the customer with a meaningful product and price-added value in order to actively retain them. Global organizations should 
be not only able to scan the economic environment but also, forecast within reasonable accuracy the economic trends. In a mature market like the United States, with un-fragmented market attributes (existing of major distributors through unified channels) it is crucial for any global organization to realize that their survival is linked to customer lifetime value. It is not only the retention of customers but also, to motivate existing customers to continually adopt their products and become "buzzer" to the organization's products. A good example on this stage is the offer that Hyundai Motor provided their new customers, the ability to work with consumers and return their purchased vehicles after one year, if the customer lost their income due to the economical down-turn. That was another strategic marketing alignment by Hyundai to win the loyalty of customer lifetime equity. Moreover, Hyundai Motor guarantees not to down-grade or show any negative marks on their customers' credit score.

Adding to the existing offer that those who buy a Hyundai and lose their job within a year can return the car, the Korean automaker is now offering 90 days of lease or loan payments while the owner looks for work. If the owner does find work in that time and decides to keep the car, the payment does not need to be repaid. (Wood, 2009, p. 1)

This global strategic vision alignment has a long term effect on mature, American consumers in terms of positive conversion to consumers' behaviors toward non-American global organizations. Take into consideration the American consumers' patriotic conviction is number one in "USA" and closely in second is Venezuela, in the world. It is an extremely intriguing example of a marketing phenomenon in the alignment of consumer behavior with self-concept in adopting Asian global products. "When it comes to national pride, Americans are No. 1, according to a survey of 34 countries' patriotism; Venezuela came in a close second in the survey" (Reichgott, 2012). American social consumer behavior is that the consumers are justified to their new consumer behavioral modification beliefs by aligning it with their patriotic convictions that Asian automotive organizations provide American jobs, and environmental green sustainability. Another indirect, positive outcome by American consumers' behavior is the driver that galvanized the used-parts market of the Japanese automotive products. Actively, it is the availability of after-market replacement parts for Japanese cars, which have less than 50,000 miles and are imported from Japan. This driver added a new value to the used part market in the United States, in which the products contain a longer warranty and a wide availability of products. Moreover, it mobilized and increased the used car dealership and parts distributions channels.

At the processing line, as professionals, we pick up parts from used cars, check each part carefully, and then only recycle the selected parts beyond our strict standards. Thanks to our careful scrapping and inspecting process, our auto parts are received high reputation on high quality and low cost. The rest of car materials are divided into each group, and then sold as high quality renewable energy source. (Kato, 2012, p. 1)

The societal marketing and environmental responsibility of the Japanese automotive products has caused the American consumers to have a positive perception toward the Asian automotive organizations. Designing products that are environmentally friendly was achieved though product recycling and fuel-efficiency. Product recycling has rejuvenated and empowered an impressive business market which has benefitted the American economy. One example is the American automotive wrecking yard which contains car crushers that can yield a healthy profit by exporting metal back to Japan.

Japanese manufacturers focused on product improvement, including technological innovations. One area of focus was making cars recyclable. By 1985, 75\% of Japanese cars, by weight, could be recycled. Japanese manufacturers also focused on safety improvements. Japan began manufacturing cars in local markets, such as the United States, as a response 
to protectionist sentiments. (Jie, 2012, p. 1)

All this has dynamic behavioral alignment effect on the consumer's attitude in providing jobs and creating customer lifetime value and customer equity.

\section{Global Organization Strategy Alignment in the Fragmented Market}

Global organizations are competing forcefully in the fragmented, spherical market on clustering location forms. Spherical market is a collection of countries that are neighboring each other and share similarities in consumer product demands. Global marketers are gathering their marketing forces on standardization marketing-pull strategy as a main driver. The pull strategy is to attract consumers to the product through product positioning that fits with consumers' self-concept. The lack of coherent distribution channels within the fragmented market can dictate the marketer to implement the pull strategy. "A fragmented system is one in which there are many retailers, no one of which has a major share of the market" (Hill, 2001, p. 539). This standardize marketing-pull strategy is designed slightly different from one location to another within the spherical market. The spherical market in this research encompasses the Arabian Peninsula and North Africa. The lack of coherent, managed distribution channels, within the fragmented market in a majority of the world market, directs the global organizations to create one country aspheric (portion of the sphere) location, marketing strategic alignment. This one country market strategy by its geographic location commonly shares similarities in consumer product demands with immediate adjacent, geographic clustering countries. This strategic alignment is achieved through standardization of the products. "Global management involves trade-offs between local subsidiaries' autonomy and headquarters' need for standardization. Cross-cultural negotiations are a fact of life for the global marketer" (Johansson, 2003, p. 79). This geographic, marketing clustering is interrelated to each other through aspheric cultural, purchasing power, self-concept, and political convictions. This research will focus on the Middle East, especially the Arabian Peninsula which has large population and more cars than any other regional countries. "Saudi Arabia is the largest country in the Middle East in terms of population and has the largest vehicle market" (AMEinfo, 2007b). Also, the research will look into North Africa's marketing sphere as one of the fragmented distribution markets. As mentioned in the previous header of the research, there are two factors which drive the majority of the products in the global market: The first factor is the product's country of origin's political orientation within the world stage; and the second factor is the customer-centered measures strategy. Both factors are cornerstones in the development of the global marketing vision in both fragmented and un-fragmented markets. In the fragmented market, the global marketer will be actively engaged in publicizing their country of origin's political orientation within the world stage. This strategic political alignment stance of the global marketers often is not admitted by the global organizations. Rather, they admit that they are engaged in humanitarian issues as part of their social responsibility and societal marketing. It is true that most Asian organizations engage in societal marketing and in mature markets as well. Toyota's effectiveness in social responsibilities mobilized the empowerment of Toyota's main distributor in Middle East, Abdul Latif Jameel Ltd. Co. (ALJ) (www.alj.com). Abdul Latif Jameel is the distributor of a host of motor vehicles of the Toyota Group (Toyota, Lexus, and Daihatsu) in 12 countries (Japan, England, Germany, China, Egypt, Monaco, Morocco, Algeria, Sudan, Saudi Arabia, Syria, and Turkey). Abdul Latif Jameel is the oldest distributor of Toyota Motor group since 1955, and ALJ is currently Toyota's largest independent distributor in the world. 
Middle East Toyota, program, has created and directed several healthcare and social development projects: Identified weakness in healthcare system and created economically viable social initiative solutions. Managed improvements at current healthcare initiatives including rehabilitation centers and healthcare training institutes. Liaised and built partnerships between international organizations, including the UN, EU, WHO, and ALJ-CSP. (Middle East Toyota, 2009, p. 3)

These engagements are important to the consumer political convictions and consumer behavior. Global organizations apply the first factor strategy on an aspheric culture, self-concept, political and purchasing power drivers of the consumers' orientation. The global organization will hardly ever admit that they are executing these strategies due to the fear of negative consequences with mature, Western market legislators and consumers, through increased tariffs and decreased quotas. The global organizations often seek help in the application of the first factor from their manufacturing country's trade ministry through the annual, international manufacturing expos held in several aspheric locations. Due to the nature of the fragmented distribution channels in many clustering locations, the global organizations have to depend on print and less television advertising. Billboards are one of the most prominent forms of advertising in these locations. All forms of outdoor advertising are utilized in this global market. Due to consumers' minimum amount of daily television viewing, the global organizations recognize that outdoor advertising is the best format in reaching large market segments of consumers. Asian products and particularly the automobile, is a great example in this fragmented market, due to the fact that vehicles are one of the products which often reflect consumer's personality, self-concept, and personal stand on world issues (environmental and political). "Research shows that a buyer purchases products that reflect and enhance the self-concept and that purchase decisions are important to the development and maintenance of a stable self-concept" (Pride \& Ferrell, 2009, p. 176). The automobile makes a widely applicable example to work diverse markets in the world. Therefore, we will be applying global automotive products as an indicator of consumer's behavior.

The high recognition of Asian products and lower recognition to European products by the Middle East and North African consumer are a positive, forward gain for Asian organizations. Acceptance of Asian products by the consumer is based on the constant neutral and stable stance of the Asian country's political orientation within the world stage. The French automotive manufacturing Renault group recorded 20,785 sales, up $23.8 \%$ over the same period a year earlier, which reinforces a large presence of French automobiles in North Africa. The French car manufacturing group reached in May of 2012, an accumulated market share of 37.9\% (MNP, 2012). The total market share percentage of French cars in Morocco is $40 \%$ for now, due to the trade and tariffs agreement with the European market but not for long, the Asian automobiles are capturing increasing market share in North Africa (Benkriane, 2006a).

Rapidly growing Asian exports could soon undermine France's 40 percent share of Morocco's car sales market. Penetration by Asian manufacturers, Japanese and Korean, is growing all the time, and in four or five years, the Chinese will also be a force. (p. 1)

The French automobile in North African markets has been steadily losing its market share to the Japanese automobile.

Ten years ago, when one thought of a car in Morocco, one thought of a French car. Unfortunately, it is no longer the same. French cars are still dominant, but we have lost a very big market share. There is a preference now for Japanese cars. (Ghanmi, 2010, p. 5) 
The Asian car market in North Africa covers more than $40 \%$ of the Moroccan market despite the high tariffs towards Japanese automotive products. Government and industry groups estimate the Japanese market share to be worth about 16.5 billion Moroccan dirhams and it is growing (Ghanmi, 2010). The first factor's successful outcome is the representation of positive market share forecast of the product. This global marketing success of achieving positive, consumer behavioral modification towards Asian and European products can constitute hurdles or barriers towards other competitive American products. At this stage, the global marketing strategic alignment must start executing the second factor: customer-centered measures strategy. The global organization should start with the product's general spherical standardization then, clustering locations' local needs standardizations with greater satisfaction of consumers. In other words, the Asian global organization's strategic alignment often exceeds the given basic needs of the spherical consumer and moves to implement strategy that pulls consumer towards the greater product-value added attributes of wants. This can translate to higher customer acquisition than other American or European organizations. A workable example of this is Toyota Motors. Toyota introduced many vehicles which are fit to the Arabian Peninsula as a clustering market location out of a spherical market group. Let us take the Toyota SUV as an example which has a crucial core benefit of the product with added value of wants in order to meet the consumer's retention behavior and avoid getting stuck in the marketing myopia. Toyota's product depth is represented in a number of SUV versions which are offered for each product in the line of the brand. The Land Cruiser's product depth, Toyota tailored the product to be not only an excellent fit for crossing the Empty Quarter Desert without stopping but also, well fit for city use. If the consumer decided to camp with this SUV in the middle of the desert, with a heat index of $125^{\circ} \mathrm{F}$ plus, there is an auxiliary air conditioner that is designed to run continually for six hours without any engine assistance. Moreover, to indulge the consumer, the drivetrain is completely sealed against sand or water, just in case of flash flooding in which the level of sand is higher than the level of the axels. This SUV has the admiration of the consumer that gives it the honorable title of the "New Desert Camel". This product's quality attributes are the right tools to create customer loyalty and life-time brand "Buzzer".

\section{Lifetime Value and Customer Equity in the Global Market}

One of the main purposes in choosing the Arabian Peninsula as a geographical, local market is in the late 1970s and 1980s the American automotive market share was the highest among the Middle East and North Africa. In 1994, the American Automotive market share in Saudi Arabia was 38.1\% and continued to decline to 29.5\% in 2006. Today, to increase the American automotive market share, America needs to capture customer lifetime value and customer equity. Due to Japanese environmental laws, car engines and transmissions must be replaced with new ones after 50,000 miles, in order for the vehicle to stay in use; otherwise the Japanese customer must buy a new vehicle. This has provided an abundance of used engines and transmission replacements in the market which increased customer lifetime value. This has not only created inexpensive after-market and available replacement parts for Japanese cars but also, created an entire new market and flourishing business to society. This global marketing strategic alignment is fortified by the first factor then constantly enforced by the new and used products that are geographical fit in the local market standardizations. The distribution channels of dealerships are one of the key drivers in the "pull marketing strategy" that is designed to achieve the second factor: customer acquisition, customer retention, customer lifetime value, and customer equity. "In the global market both strategy, pull and push market distribution can be utilized" (Baack \& Harris, 2013, p. 385). The "push marketing strategy" can be utilized successfully, especially in a developed 
to a mature market. This is due to the existence of consumer's maturity and the country's infrastructure. Often, this is not the case in the Middle East. The percentage of 17.9\% market share in 2012 is representing Ford with 6.3\%, GM with 10.2\%, and Dodge with 1.4\% (Bestsellingcar, 2012, p. 1). We can clearly see the decline of the American market share since 1994. Historical average percentage scale (percentage scale factored in) of $8.6 \%$ was extracted from 2012, 2006, and 1994 market share to be utilized to add 8.6\% every 12 years starting from 1982 to 1970, one can extract a reasonable and workable correlation result that can apply before 1994 as shown in Table 1 and its rationale, the American automotive market share in Arabian Peninsula was progressively higher as we go back from 1994 to 1982 and 1970. As for the Japanese automotive market share, they reached a prosperous percentage of 58.0\% in 1994 and continue growth in their market share to 62.5\% in 2006 (AMEinfo, 2007b). In 2012, the Japanese market share is $48.1 \%$ which represents $40.2 \%$ for Toyota and $7.9 \%$ for other Japanese automotive brands. This lowered percentage can be very well accredited to the strength of the Korean brand market share of $26.1 \%$ in the Arabian Peninsula as a substitute product to Japanese product (Bestsellingcar, 2012, p. 2). The Arabian consumers' self-concept beliefs about Korean brands as a substitute product are within their alignment of loyalty towards Japanese products. The Arabian Peninsula is the strongest American ally in the Arab World and has the cheapest gas prices in the world, which should make them an excellent, welcoming market to the American automotive products but instead is not. The American brand market share in 2006 was 29.5\%, and in 2012 is only 17.9\% (AMEinfo, 2007a, p. 2). The Asian automobile products represent more than $71 \%$ of vehicle market in 2007. Japanese brands market share is $62.5 \%$ and Korean brands market share is $8.5 \%$. The European brand market share is $6.2 \%$. Today, KIA Motor has a positive increase in the Asian market share in the Middle East and in the North African market. From 1994 and later (1994-2006), the Korean automotive market share was $0.5 \%$ and gained $8.5 \%$ in the market share between 2004 and 2006 (AMEinfo, 2007a, p. 1). In the Arabian Peninsula, the 2012 market share percentages of Korean automobiles are $19.8 \%$ for Hyundai and $6.3 \%$ for KIA, which makes a total of 26.1\%. In 2012, in the Arabian Peninsula, the European automotive market share was $2.4 \%$. This percentage was distributed among Germany having $1.1 \%$, and the France $1.0 \%$, and only $0.3 \%$ for the United Kingdown (AMEinfo, 2007a, p. 2).

\section{Rationale for Table 1}

The Japanese automotive industry's lack of product maturity competitiveness from 1970 to 1982, coupled with the American stronghold on the Arabian Peninsula's market has made it difficult to obtain market share data. Therefore, Table 1 was constructed to clarify the rationale and the applications of the market share percentages from 1970 to 1982 . The following application was utilized as follows: For the American market share percentage scale (percentage scale factored in) 8.6\% was added every 12 years starting from 1982 to 1970 as shown in Table 1 and was continued every 12 years. The $8.6 \%$ came from subtracting the 2006 market share of $29.5 \%$ from the 1994 market share of $38.1 \%$, resulting in $8.6 \%$. The percentage $8.6 \%$ represents the growth of market share for American automobiles as we move back from 1982 to 1970 . Therefore, $8.6 \%$ was added to $1994 \mathrm{~s}$ market share of $38.1 \%$ which resulted in $46.7 \%$ as the market share for 1982 . Also, $8.6 \%$ was added to 1982 's market share of $46.7 \%$, this gave us $55.3 \%$ as the market share for 1970 . Matured, American, market strategy and simplistic, consumers' political behavior in the Arabian Peninsula caused the American market share to be at an all-time high during the 1970s thru 1994.

The Japanese automobiles increased in market share partly due to Americans' loss of market share during 1970 thru 1982. This became a gain for the Japanese market share from 1970 to 1982 . We utilized the 
difference in American market share between 1982 and 1994 to calculate the rate of change in American market share. In 1982, the market share of $46.7 \%$ was subtracted from 1994's market share of $38.1 \%$. That gave us the $8.6 \%$ difference. The difference of $8.6 \%$ divided by 1994's 38.1\% of American shares, gives us 23\% as the rate of change in American market share between 1994 and 1982. Subtracted the rate of change $23 \%$ from Japanese market share in 1994 of 58\%, this gave us 35\% as a market share for Japanese in 1982. The same method of calculation was repeated for the difference in American market share between 1970 thru 1982. 1970 of $55.3 \%$ subtracted from 1982 of $46.7 \%$ gave the difference of $8.6 \%$. Then $8.6 \%$ divided by 1982 's American share of $46.7 \%$ gave $18.5 \%$, the rate of change from 1970 to $1982,18.5 \%$ rate of change subtracted from Japanese market share in 1982 of $35 \%$ gave $16.5 \%$ as a market share for Japanese in 1970. The immaturity in the Japanese marketing strategy from 1970 to 1982 and product incompatibly caused a declined pattern in the market share from 1970 to 1982.

Table 1

Asian \& American Automobile Market Share in the Arabian Peninsula 1970-2012

\begin{tabular}{|c|c|c|c|c|c|}
\hline & Market share & Market share & $\begin{array}{l}\text { Market } \\
\text { share }\end{array}$ & $\begin{array}{l}\text { Market } \\
\text { share }\end{array}$ & $\begin{array}{l}\text { Market } \\
\text { share }\end{array}$ \\
\hline Country of origin & Year 1970 & Year 1982 & Year 1994 & Year 2006 & Year 2012 \\
\hline $\begin{array}{l}\text { American: scale factor increase by } 8.6 \% \text { every } 12 \\
\text { years between } 2006-1970\end{array}$ & $\begin{array}{l}55.3 \% \text { scale factored } \\
\text { in }\end{array}$ & $\begin{array}{l}46.7 \% \text { scale factored } \\
\text { in }\end{array}$ & $38.1 \%$ & $29.5 \%$ & $17.9 \%$ \\
\hline $\begin{array}{l}\text { Japanese: rate of change factor out, subtracted by } \\
23 \% \text { in } 1982 \text { and } 18.5 \% \text { in } 1970 \text { every } 12 \text { years }\end{array}$ & $\begin{array}{l}16.5 \% \text { (rate of } \\
\text { change factored out) }\end{array}$ & $\begin{array}{l}35.0 \% \text { (rate of } \\
\text { change factored out) }\end{array}$ & $58.0 \%$ & $62.5 \%$ & $48.1 \%$ \\
\hline Korean & did not exist & did not exist & $0.5 \%$ & $8.5 \%$ & $19.8 \%$ \\
\hline
\end{tabular}

Percentage scale factored in was used to add 8.6\% every 12 years starting from 1982 to 1970 for American automobile. Japanese automobile percentage rate of change was used to subtract every 12 years starting from 1982 to 1970 (AMEinfo, 2012; Bestsellingcar, 2012).

\section{Global Marketing Factors in Business Applications}

The American automotive industry continues to struggle in the Arab World market and truly needs to take a realistic analytical look at the first factor effect on their global market. Someone might say well, look at our American market share in the 1970s and 1980s, America did very well during these years. The realistic, analytical look is to be able to accept your short comings and work on transforming your weaknesses to opportunities and then to strengths. Also, to recognize the dynamic effect of the first factor on the global market and not write it off as a market glitch. This means that a global organization should understand the given dynamic market culture and not only accept it but also, be in love with it, in order to transform consumer behavior to the global organizations' benefits. One of the main reasons that American products did well from the 1970s to 1980s is due to the destruction of the European and Asian infrastructure during World War II and most often, the victor writes the history and sets the policies. America's foreign policy has a determined focus for dominance thru the search of many surrogates in the Arab/Muslim World to mirror its dominant mentality, then expand on this ideology from political to the consumer market. This often leaves the American to be closed-minded in their analytical views towards their products' market share. "American and European car sales have not fared as badly. Although American cars dropped 25\%, dealers say the rising price of the yen against the dollar kept them from declining further" (Kaiser, 2012). Mainly, the first factor effect is when the product's country of origin's political orientation, within the world stage, comes into real conflict with the 
consumer's political behavior. American foreign policy is seen in the Middle East and North Africa as a negative stance toward the Arab World by a majority of 1.6 billion consumers in the Muslim world, which represents $23 \%$ of the world population (Desilver, 2013, p. 1). The realities of a strong presence of Islamic political views in Saudi Arabia are a powerful motivator and influencer on consumers' behavior in not adopting American products. Also, the presence of Islamic political views coupled with Arab nationalism in North Africa drives, to some degree, the consumers' behavior towards not adopting the American products.

Islam is not just a religion; it is also the source of law, a guide to statecraft, and an arbiter of social behavior. Muslims believe that every human endeavor is within the purview of the faith and this includes political activity. (Hill, 2011, p. 89)

As for the second factor, the global organization needs to continually be innovative in their products and strive to exceed customers' needs and wants, in order to create and retain customer equity.

\section{Conclusions}

The first research factor in this paper is the product's country of origin's political orientation within the world stage. This is centralized around the relationship of the country's product foreign policy towards world affairs, as stated throughout the research. Often, the manufacturing country has a profound effect on the consumers' thinking and behavior towards that country's products. In the 1960s, Japanese automobiles were looked at as low quality products. Furthermore, Japan had a war stigma which was the bombing of Pearl Harbor. Many Americans believed that buying a Japanese car was truly an unpatriotic consumer behavior. In the 1960s, the Japanese automobile market share in United States did not even exist. In fact, in 1957 Toyota exported the first compact car to the U.S., only to be humiliated and finally pulled the product off the market.

Two tiny sedans left the port of Yokohama in August 1957, bound for California - the first exports from Toyota. The four-door clunkers flopped. The car, which looked like a brick with a roof on top, was prone to overheating and vibrated at speeds of more than 60 miles per hour. By late 1960, Toyota realized it had made a mistake and pulled the Toyota Crown off the market. (Taylor, 2007, p. 1)

The successful global organization believes and truly understands the effect of the first factor, which is the gateway to overcoming greater consumer barriers and entry to many global markets. The Asian global organizations quickly recognized that the product's country of origin's political orientation within the world stage and believed it as a crucial, forceful barrier. Many successful global organizations might not admit that strategic alignment recognition of the first factor is due to the fear of retaliation by consumers and legislators of a global, mature market. A successful global marketer will strategically plan and execute the first factor which is that the product's country of origin's political orientation aligns within the world stage. As a result of understanding and overcoming the first factor barrier in the American market in 1978, the Japanese automotive market share reached 25\%, and in 1982, it became 30\% (Halberstam, 1986, p. 32). In 2012, Japanese automotive market share is $37 \%$ and Korean automotive market share is $9.0 \%$. This brings the total of Asian automotive market share to $46 \%$. The American automotive market share of the Big Three in 2012 is a total of 49.3\% (Wall Street Journal, 2012).

The global marketers should recognize that the source effect theory is designed to minimize or maximize the source effects (product country of origin) on the global consumers' behaviors in a positive manner, in order to benefit the global organization. If the behavior of the products' country of origin on the world stage is in conflict with today's empowered consumer, this will result in the lack of adoption of the product. There can be 
many variables which can influence consumer behaviors in the adoption of a product. Some of the most powerful variables or factors are those which come either in conflict or agreement with the way the consumer sees her/him self-concept as an active partner through personal beliefs within the world's resources and political stances. Therefore, we should not be surprised that consumers' political and environmental beliefs are crucial factors in the consumers' behavior towards the adoption of products that require considerable time and financial investments. Toyota-Prius owners are adopting the product partially for gas efficiency but also, for the alignment of their self-concept with the love of a green environment. These political factors become more prominent especially in a market with a collectivism culture such as the Middle East and North Africa as environmental concerns becoming more prevalent. This market based on collectivism culture runs deep in relations to a larger, spherical, and global market, which contains many integrated behavioral variables which can mobilize the consumers' buying decisions. "The ability to source and sell on a global basis requires understanding of cultural and ethnic variables" (Engel, Blackwell, \& Minnard, 1982, p. 394).

\section{Limitations and Recommendations for Future Research}

This study examined how the consumer's self-concept affects consumer behavior in adoption to any product and how global organizations align its strategy to fit consumers' self-concepts. The limitation this paper experienced was the unclear recognition on the part of global organizations to their representatives' government's political orientation within the world stage. These limitations resulted from the lack of global organizations engagement with their sanctuary market government's foreign policy. This limitation created obstacles to fully understand the degree of communication levels and engagements between the global organizations and their represented government. Other limitations to this study are the degree of effectiveness and persuasion of global organizations on their represented government in aligning government foreign policy with the benefits of the global organizations. Moreover, as future recommendation, the relationship between consumer self-concepts and product adoption should be conducted, with direct integration of the global organizations' input for future research, to illustrate stronger outcomes to the reader.

\section{References}

AMEinfo. (2007a). The Saudi Arabian automobile market abstract. Retrieved from http://www.ameinfo.com AMEinfo. (2007b). The ultimate middle east business resources abstract. Retrieved from http://www.ameinfo.com AMEinfo. (2012). All-new third-Generation Kia Cerato Sedan. Retrieved from http://www.ameinfo.com Baack, D., \& Harris, E. (2013). International marketing. Thousand Oaks, C.A.: SAGE Publication.

Benkriane, A. (2006a). French auto industry in Morocco. Retrieved from http://www.skyscrapercity.com/showthread.php?t=744232

Benkriane, A. (2006b). Morocco auto market share. Retrieved from http://www.worldeyereports.com

Bestsellingcar. (2012). The Saudi car market accounts for roughly half of the gulf corporation council. Retrieved from http://www.bestsellingcarblog.com

Desilver, D. (2013). World's muslim population more widespread than you think. Retrieved from http://www.pew.research.center.org

Engel, J., Blackwell, R., \& Minnard, P. (1982). Consumer behavior (5th ed.). New York, N.Y: The Dryden Press.

Ghanmi, L. (2010). Morocco tariffs to hit Asian car imports lobby. Retrieved from http://www.UK.Reuters.com

Halberstam, D. (1986). The reckoning. New York, N.Y.: William Morrow and Company Publishing.

Hill, C. W. L. (2001). International business (3rd ed.). New York, N.Y: McGraw Hill.

Hill, C. W. L. (2004). Global business today (3rd ed.). New York, N.Y: McGraw Hill/Irin.

Jackson, S., \& Schuler, R. (2003). Managing human resource (8th ed.). Mason, O.H.: South Western.

Jie, M. W. (2012). The history of Japanese autos. Retrieved from 
http://www.ehow.com/about_5318303_history-japanese-autos.html\#ixzz228tQ60lv Johansson, J. K. (2003). Global marketing (3rd ed.). New York, N.Y: McGraw Hill.

Kaiser, D. (2012). Ford turns to slumped Saudi market. Retrieved from http://www.FloridaPublishing.com Kato, K. (2012). Exporting high-quality Japanese used auto parts to global market. Retrieved from http://www.Alibaba.com Middle-East Toyota. (2009). Social responsibility of Toyota in Middle East. Retrieved from http://www.Linkedin.com MNP. (2012). Renault group's car sales in Morocco account for $38 \%$ up to late May. North Africa United News.

Pride, W. M., \& Ferrell, O. C. (2009). Marketing express (p. 176). Boston, M.A.: Houghton Mifflin Company.

Reichgott, M. (2012). Americans have the most national pride. New York: Associated Press.

Taylor, A. III. (2007). America's best car company: Toyota has become a red-white and blue role model. Fortune Magazine (p. 5).

Trading Economics. (2013). United States output gap in percent of potential GDP. Retrieved from http://www.tradingeconomics.com

Wall Street Journal. (2012). Sales and share of total market by manufacturer. The Wall Street Journal (p. 1).

Wood, C. (2009). Hyundai returns policy gets even better. Retrieved from http://www.autoGuide.com

WTO. (2011). Merchandise exports and imports. Retrieved from http://www.WTO.org 